\title{
Extrachromosomal DNA in Chloramphenicol Resistant Myxococcus Strains
}

\author{
BY N. L. BROWN AND J.H. PARISH \\ University of Leeds, Department of Biochemistry, Leeds LS2 $9 L S$
}

(Received I4 May 1975; revised I6 September 1975)

S UMMAR Y

The presence of extrachromosomal DNA in strains of Myxococcus xanthus and $M$. fulus was examined by rate-zonal centrifugation of radioactively-labelled DNA in 'cleared lysates'. All the strains examined contained extrachromosomal DNA, with the exception of $M$. xanthus $\mathrm{FB}_{\mathrm{t}}$. Chloramphenicol resistance is inducible in $M$. xanthus $\mathrm{FB}_{\mathrm{t}}$. A peak of extrachromosomal DNA, containing covalently closed molecules, was found in one of the induced strains, implying that induction of chloramphenicol resistance is associated with the production of a plasmid.

By incubating $\mathrm{R}^{+}$strains of Escherichia coli with myxococci, R factor-mediated chloramphenicol resistance can be introduced into the latter. Evidence of extra chromosomal DNA in a derivative of $M$. xanthus with chloramphenicol resistance from R factor R I . I 9 unique to the chloramphenicol strain, was obtained. By using a double-labelling technique, several chloramphenicol-resistant strains of M. fulvus M were examined. Evidence for a peak, unique for the chloramphenicolresistant strain, was found in a strain with resistance derived from the $\mathrm{R}$ factor, $\mathrm{S}-\mathrm{a}$, but not from comparable strains with resistance derived from $R$ factors $R 57 b$, RI . I9 and R478.

\section{INTRODUCTION}

The genus Myxococcus comprises certain members of the order Myxobacteriales (Gramnegative rods with a complex morphogenetic cycle involving the formation of fruiting bodies) which have a resting form, myxospores, grossly different in morphology from the vegetative organisms. Inducible chloramphenicol resistance has been obtained in M. fulvus $\mathrm{M}$ (Parish, 1975) and $M$. xanthus $\mathrm{FB}_{\mathrm{t}}$ (Burchard \& Parish, 1975). Additionally, resistance to several drugs can be transferred to $M$. xanthus and $M$. fulvus by incubating myxococci with cultures of Escherichia coli harbouring R factors (Parish. 1975). In all cases examined, chloramphenicol resistance is mediated by acetylation of the drug (Parish, 1975; Burchard \& Parish, 1975). We have examined the extrachromosonal DNA in 'cleared lysates' of bacteria by using techniques similar to those designed for $E$. coli by Guerry, LeBlanc \& Falkow (1973), with a view to establishing the molecular basis for chloramphenicol resistance in myxococci.

\section{METHODS}

Chemicals and media. Tris and deoxyadenosine were obtained from Sigma; other chemicals were obtained from $\mathrm{BDH}$ and were of AnalaR grade where possible. Agar was obtained from Laboratory Industrial and Pharmaceutical Services Ltd, London; other media were obtained from Difco, and chloramphenicol from Parke-Davis Ltd, Hounslow, Middlesex. Radiochemicals were obtained from the Radiochemical Centre, Amersham, Buckinghamshire. 


\section{Table I. Bacterial strains}

\begin{tabular}{|c|c|c|c|c|}
\hline Species & Strain & $\begin{array}{l}\text { Relevant } \\
\text { markers }\end{array}$ & $\begin{array}{l}\text { Origin of } \\
\text { chloramphenicol } \\
\text { resistance }\end{array}$ & Reference \\
\hline Myxococcus xanthus & $\begin{array}{l}\text { A } \\
\text { AI } \\
\mathrm{AI}_{(\mathrm{I}}(\mathrm{R} \cdot \mathrm{I}) \mathrm{cml} \\
\mathrm{FB}_{\mathrm{t}} \\
\mathrm{FB}_{\mathrm{t}}-\mathrm{I} \mathrm{cml}\end{array}$ & $\begin{array}{l}\text { rif } \\
\text { rif } \\
\text { pig } \\
\text { cml pig }\end{array}$ & $\begin{array}{l}\overline{-} \\
\mathrm{R}^{+}+\overline{\text { coli }} \\
\text { Endogenous }\end{array}$ & $\begin{array}{l}\text { Parish (1975) } \\
\text { Parish (1975) } \\
\text { Parish (1975) } \\
\text { Burchard \& Dworkin (1966) } \\
\text { Burchard \& Parish (1975) }\end{array}$ \\
\hline M. fulvus & $\begin{array}{l}\mathrm{M} \\
\mathrm{M}(\mathrm{RI} \cdot \mathrm{I}) \mathrm{cml} \\
\mathrm{M}(\mathrm{R} 478) \mathrm{cml} \\
\mathrm{M}(\mathrm{R} 57 \mathrm{~b}) \mathrm{cml} \\
\mathrm{M}(\mathrm{S}-\mathrm{a}) \mathrm{cml}\end{array}$ & $\begin{array}{l}\mathrm{cml} \\
\mathrm{cml} \\
\mathrm{cml} \\
\mathrm{cml}\end{array}$ & $\begin{array}{l}\quad- \\
\mathrm{R}^{+} E . \text { coli } \\
\mathrm{R}^{+} E \text {. coli } \\
\mathrm{R}^{+} \text {E. coli } \\
\mathrm{R}^{+} \text {E. coli }\end{array}$ & $\begin{array}{l}\text { Parish (1975) } \\
\text { Parish (1975) } \\
\text { Parish (1975) } \\
\text { Parish (1975) } \\
\text { Parish (1975) }\end{array}$ \\
\hline
\end{tabular}

$\mathrm{cml}$, resistance to chloramphenicol; rif, resistance to rifampicin; pig, pigment.

Myxococcus strains were maintained on plates of I \% (w/v) Bactocasitone-I.5 $5 \%(\mathrm{w} / \mathrm{v})$ agar and were grown in shake culture at $30{ }^{\circ} \mathrm{C}$ in $1 \%(\mathrm{w} / \mathrm{v})$ vitamin-free Bactocasitone supplemented with $\mathrm{CaCl}_{2}\left(\mathrm{IO}^{-3} \mathrm{M}\right)$; this medium is referred to as VFCa. Plates and liquid cultures used for growth of chloramphenicol-resistant strains contained chloramphenicol $(25 \mu \mathrm{g} / \mathrm{ml})$.

Bacterial strains. Strains used in this work are listed in Table I. The characterization of chloramphenicol-resistant strains is described by Parish (I975).

Preparation of cleared lysates. Bacteria were grown in VFCa medium (containing chloramphenicol for chloramphenicol-resistant strains) to mid-exponential phase $\left(E_{540} 0 \cdot 2\right.$ to 0.6$)$ and I $\mathrm{ml}$ was transferred to fresh medium $(50 \mathrm{ml})$, containing deoxyadenosine $(25 \mu \mathrm{g} / \mathrm{ml})$ and either $\left[\right.$ methyl $\left.-{ }^{3} \mathrm{H}\right]$ thymidine $(5 \mu \mathrm{Ci} / \mathrm{ml} ; 56 \mathrm{Ci} / \mathrm{mmol})$ or $\left[\right.$ methyll $\left.-{ }^{14} \mathrm{C}\right]$ thymine $(0.5 \mu \mathrm{Ci} /$ $\mathrm{ml} ; 60 \mathrm{mCi} / \mathrm{mmol}$ ), and were grown to mid-exponential phase. The mean generation time of the strains was between 10 and $20 \mathrm{~h}$. The bacteria were harvested and washed twice with VFCa medium by centrifugation. The bacteria were lysed in detergent and strong salt by the method of Guerry et al. (1973). The lysate was cleared by centrifugation at $20000 \mathrm{~g}$ for $45 \mathrm{~min}$ at $4{ }^{\circ} \mathrm{C}$. The supernatant was dialysed against Io mm-EDTA, $0.15 \mathrm{M}-\mathrm{NaCl}, 0.0 \mathrm{I} 5 \mathrm{M}-$ sodium citrate at $4{ }^{\circ} \mathrm{C}$. For experiments in which double labelling was employed, the two cultures labelled separately with $\left[{ }^{14} \mathrm{C}\right]$ thymine and $\left[{ }^{3} \mathrm{H}\right]$ thymidine were pooled before the initial harvesting.

Sucrose-gradient centrifugation. Sucrose gradients were centrifuged in the $\mathrm{SW}_{39} \mathrm{~L}$ rotor of the Beckman model $\mathrm{L}$ ultracentrifuge at speeds and periods of time corresponding to between $1.0 \times 10^{7}$ and $2.7 \times 10^{7} \mathrm{~g}$ min. Details are described in the legends to the Figures. Neutral sucrose gradients were prepared according to the method of Burgi \& Hershey (1963). Alkaline sucrose gradients were prepared according to the method of Abelson \& Thomas (I966). Fractions were collected from gradients by the method of Flamm, Birnstiel \& Walker (1972).

The amount of radioactivity incorporated into the DNA of myxococci by these techniques is limited, and for strain AI and some of the derivatives, insufficient radioactivity was incorporated for analysis (see Results). The small amounts of radioactivity available throughout limited the further analysis of fractions from sucrose gradients and, in particular, rendered impossible the resolution of the complexity of the heterodisperse cryptic extrachromosomal material which was found in all the strains we examined, with the exception of $M$. xanthus $\mathrm{FB}_{\bullet}$. 


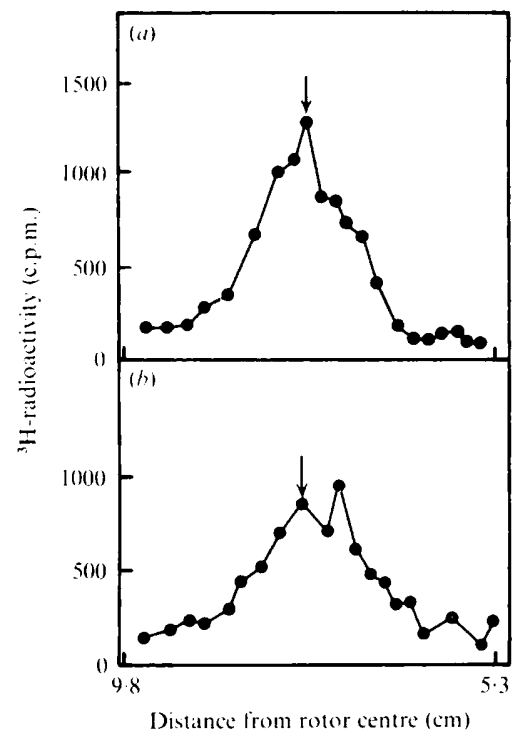

Fig. I

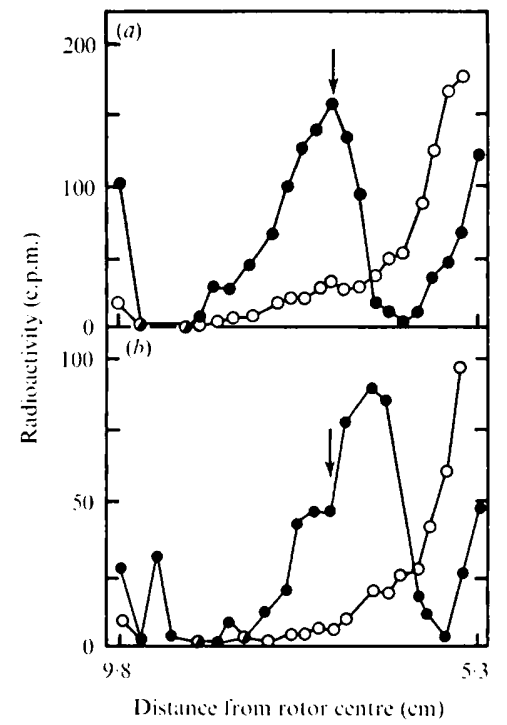

Fig. 2

Fig. 1. Extrachromosomal DNA in $M$. xanthus A. A cleared lysate of bacteria labelled with [methyl $-^{3} \mathrm{H}$ ] thymidine was prepared. (a) A portion $(0.05 \mathrm{ml})$ was layered over a gradient of sucrose ( 5 to $20 \%, \mathrm{w} / \mathrm{v}$ ) in $0.5 \mathrm{M}-\mathrm{NaCl}-0.0 \mathrm{I}$ M-potassium phosphate buffer, $\mathrm{pH} 7.0(5 \mathrm{ml})$. (b) Sodium hydroxide ( $\mathrm{I} \mathrm{M} ; 0.0 \mathrm{I} \mathrm{ml}$ ) was added to lysate $(0 . \mathrm{I} \mathrm{ml})$ at $0^{\circ} \mathrm{C}$. After $\mathrm{I} 0 \mathrm{~min}$, a portion $(0.05 \mathrm{ml})$ was layered over a gradient of sucrose ( 5 to $20 \%, \mathrm{w} / \mathrm{v}$, in $5 \mathrm{ml}$ of $0.9 \mathrm{M}-\mathrm{NaCl}-0 . \mathrm{I} \mathrm{M}-\mathrm{NaOH}, \mathrm{pH}$ i I 4 ). Gradients were centrifuged in the SW $39 \mathrm{~L}$ rotor of the Beckman model L2-65B ultracentrifuge for $300 \mathrm{~min}$ at $117000 \mathrm{~g}$ and $15{ }^{\circ} \mathrm{C}$. Arrows indicate the peak of radioactivity in the neutral gradient (a) and the position to which such material would sediment at $\mathrm{pH}$ il $\cdot 4(b)$, if it consisted of covalently closed DNA molecules.

Fig. 2. Extrachromosomal DNA in $M$. xanthus $\mathrm{FB}_{\mathrm{t}}-\mathrm{I}$ chl. Cultures of $M$. xanthus $\mathrm{FB}_{\mathrm{t}}$ labelled with $\left[2-{ }^{14} \mathrm{C}\right]$ thymine and $M$. xanthus $\mathrm{FB}_{\mathrm{t}}-\mathrm{I}$ chl labelled with $\left[\right.$ methyl $\left.-{ }^{3} \mathrm{H}\right]$ thymidine were mixed, and cleared lysates were prepared and fractionated by centrifugation in $(a)$ neutral and $(b)$ alkaline sucrose gradients as described in the legend to Fig. I. Centrifugation was for $435 \mathrm{~min}$ at $1 \mathrm{I} 7000 \mathrm{~g}$ and $10{ }^{\circ} \mathrm{C}$.,${ }^{3} \mathrm{H}$-radioactivity; $\mathrm{O},{ }^{14} \mathrm{C}$-radioactivity. Arrows indicate the peak of ${ }^{3} \mathrm{H}$-radioactivity in the neutral gradient $(a)$ and the position to which such material would sediment at $\mathrm{pH} \mathrm{II} \cdot 4(b)$, if it consisted of covalently closed DNA.

Assay of radioactivity. Fractions from sucrose gradients were diluted fourfold with water and fluor solution ( $5 \mathrm{~g}$ 2,5-diphenyloxazole and $100 \mathrm{~g}$ naphthalene/l in I,4-dioxane) was added. The samples were counted in the Beckman LS20o liquid scintillation spectrophotometer to the standard error of $5 \%$. For double-labelled samples quench correction and channeloverlap corrections were made.

\section{RESULTS}

DNA was found in cleared lysates of all myxococci studied with the exception of M. xanthus $\mathrm{FB}_{\mathrm{t}}$. In most strains the DNA formed a broad envelope in sucrose gradients, implying a heterogeneous population of extrachromosomal DNA molecules; Fig. I, for example, shows the distribution of DNA from $M$. xanthus A. A comparison of the pattern of sedimentation at $\mathrm{pH} 7 \cdot 0$ (Fig. I $a$ ) with that at $\mathrm{pH}$ I I 4 (Fig. I $b$ ) suggests that most of the species are covalently closed, because covalently closed molecules have the same sedimentation coefficient at these two $\mathrm{pH}$ values (Abelson \& Thomas, 1966).

We examined the distribution of DNA from cleared lysates in several chloramphenicol- 


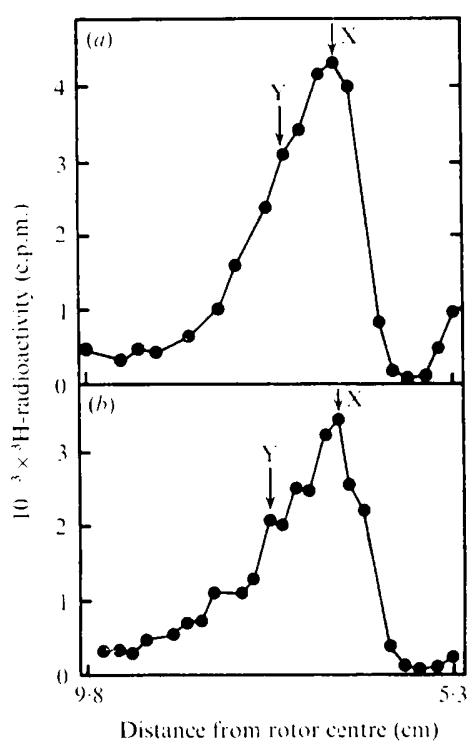

Fig. 3

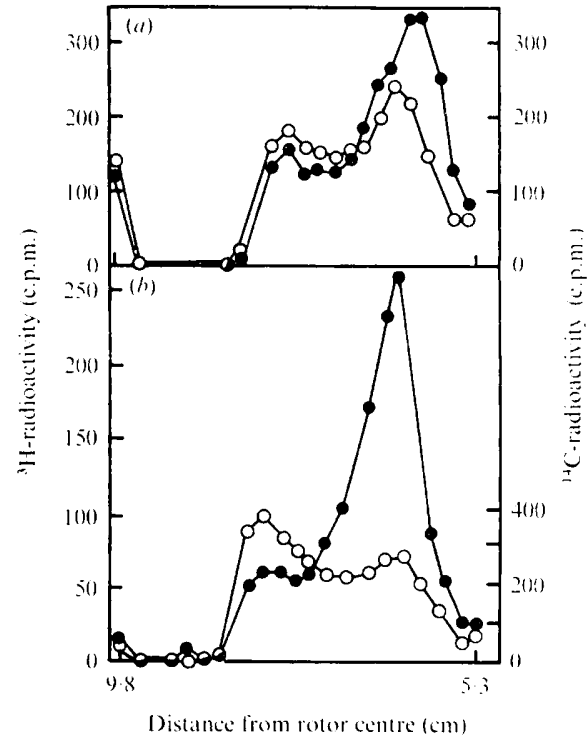

Fig. 4

Fig. 3. Extrachromosomal DNA in $M$. xanthus AI (RI . I9) chl. A cleared lysate was prepared and sedimented through $(a)$ neutral and $(b)$ alkaline sucrose gradients as described in the legend to Fig. I. Centrifugation was for $450 \mathrm{~min}$ at $83000 \mathrm{~g}$ and $10{ }^{\circ} \mathrm{C}$. For a discussion of the positions $\mathrm{X}$ and $\mathrm{Y}$, see Results.

Fig. 4. Extrachromosomal DNA in strains of $M$. fulvus. Myxococcus fulvus strains were labeiled with either $\left[\right.$ methyl $\left({ }^{3} \mathrm{H}\right]$ thymidine or $\left[2-{ }^{14} \mathrm{C}\right]$ thymine. Cultures were mixed and cleared lysates were obtained and centrifuged through neutral sucrose as described in the legend to Fig. I. $(a){ }^{14} \mathrm{C}$ labelled $M$. fulvus $\mathrm{M}$ and ${ }^{3} \mathrm{H}$-labelled $M$. fulvus (R57b) chl; $(b){ }^{14} \mathrm{C}$-labelled $M$. fulvus $\mathrm{M}$ and ${ }^{3} \mathrm{H}$-labelled $M$. fulvus $\mathrm{M}(\mathrm{S}-\mathrm{a})$ chl. Centrifugation was for $105 \mathrm{~min}$ at $117000 \mathrm{~g}$ and $\mathrm{I} 5{ }^{\circ} \mathrm{C}$. ${ }^{3} \mathrm{H}$-radioactivity; $\mathrm{O},{ }^{14} \mathrm{C}$-radioactivity.

resistant strains. In general, we employed a double-labelling procedure in which cultures of chloramphenicol-sensitive organisms labelled with $\left[{ }^{14} \mathrm{C}\right]$ thymine were mixed with chloramphenicol-resistant organisms labelled with $\left[{ }^{3} \mathrm{H}\right]$ thymidine, and cleared lysate DNA was isolated from the mixture. Variations in extrachromosomal DNA yield from preparation to preparation were thus reduced. This procedure was not possible for $M$. xanthus AI (RI.19) $\mathrm{cml}$. The parent strain $M$. xanthus AI and chloramphenicol-sensitive strains obtained from cultures of $M$. xanthus AI(RI . I9) are not identical, as the latter strains differ from the parental strain AI with respect to the stability of the rifampicin marker (Parish I975). Moreover, we were unable to incorporate sufficient radioactivity from either thymine or thymidine into the DNA of the chloramphenicol-sensitive AI(RI.I9) derivatives for sucrose-gradient analysis.

The analysis of DNA in cleared lysates of $M$. xanthus $\mathrm{FB}_{\mathrm{t}}$ and $\mathrm{FB}_{\mathrm{t}}-\mathrm{I} \mathrm{cml}$ revealed a peak of extrachromosomal DNA in strain $\mathrm{FB}_{\mathrm{t}}^{-1} \mathrm{cml}$ absent from the DNA of chloramphenicolsensitive parent (Fig. 2). The changed distribution in the alkaline gradient (Fig. $2 b$ ) implies that although the preparation contains much DNA that is not covalently closed, possibly due to the presence of ' nicked circles', there is a proportion of covalently closed molecules.

The distribution of DNA from strain AI(RI.19) $\mathrm{cml}$ shows a peak of radioactivity (position $\mathrm{X}$ in Fig. 3) which is unchanged at $\mathrm{pH} \mathrm{II}_{4}$ (Fig. $3 b$ ). Position $\mathrm{Y}$ shows the anticipated peak of activity for $M$. xanthus A in such gradients. As there is some loss of this peak 
to more slowly sedimenting forms at $\mathrm{pH}$ i I 4 (Fig. I), the loss of radicactivity at position $\mathrm{Y}$ in Fig. $3(b)$ is consistent with the partial denaturation of this endogenous material and a retention of the covalently closed structure of a plasmid derived from R $\mathrm{R} .19$ in M.xanthus, sedimenting to position $\mathrm{X}$.

Several $\mathrm{R}^{+}$strains derived from $M$. fulvus $\mathrm{M}$ were isolated by Parish (I975). The analysis of the DNA from these strains was complicated by the large amount of $M$. fulvus extrachromosomal DNA revealed by the technique. Analysis of two doubly-labelled preparations are shown in Fig. 4. Myxococcus fulvus $\mathrm{M}(\mathrm{R} 576) \mathrm{cml}$ (Fig. 4a) shows no clear evidence for the presence of plasmid in the $\mathrm{R}^{+}$strain although the higher ${ }^{3} \mathrm{H}:{ }^{14} \mathrm{C}$ ratio in the upper part of the gradient may reflect the presence of a plasmid characteristic of the $\mathrm{R} 576 \mathrm{cml}$ marker. In $M$. fulvus $\mathrm{M}(\mathrm{S}-\mathrm{a}) \mathrm{cml}$ (Fig. $4 b$ ) there is a large peak of ${ }^{3} \mathrm{H}$-radioactivity implying the presence of a plasmid in the $\mathrm{R}^{+}$strain.

Analysis by the same technique of DNA from strains $\mathrm{M}\left(\mathrm{R}_{\mathrm{I}} \cdot \mathrm{I}\right) \mathrm{cml}$ and $\mathrm{M}(\mathrm{R} 478) \mathrm{cml}$ (not shown) produced profiles similar to that shown for $\mathrm{M}(\mathrm{R} 57 \mathrm{~b})$ in Fig. $4(a)$. This suggests that either there is no plasmid characteristic of the resistant strains or that the molar yield of $\mathrm{R}$ factor is much lower than that of the endogenous extrachromosomal DNA.

\section{DISCUSSION}

The presence of extrachromosomal DNA in myxococci has been demonstrated for the first time, by comparing sedimentation patterns at $\mathrm{pH} 7 \cdot 0$ and $\mathrm{pH}$ II 4 to discriminate between covalently closed DNA and other classes of DNA. This procedure is based on the finding that the alkali-mediated helix-coil transition for the covalently closed DNA occurs at $\mathrm{pH}$ I I. 6 to $1 \mathrm{I} \cdot 8,0.5 \mathrm{pH}$ units higher than that of linear and open-circular DNA (Vinograd, Lebowitz \& Watson, I968).

The discovery of a plasmid in $M$. xanthus $\mathrm{FB}_{\mathrm{t}}-\mathrm{I} \mathrm{cm} /$ suggests two modes of origin of drug resistance: either a cryptic gene in the parent strain, $\mathrm{FB}_{\mathrm{t}}$, is expressed only following segregation of a plasmid, or the chloramphenicol resistance gene is borne on a plasmid that is amplified following induction. Plasmids homologous to chromosomal DNA have been demonstrated in Bacillus megaterium (Hennebury \& Carlton, 1973; Carlton \& Smith, I974), suggesting that certain bacterial genes can be present either in an integrated form in the chromosome or as extrachromosomal elements. The present results with $M$. xanthus $\mathrm{FB}_{\mathrm{t}}$ suggest that there might exist a class of genes which are only expressed following segregation of a plasmid.

The presence of plasmids associated with drug resistance in $M . f u l v u s \mathrm{M}(\mathrm{S}-\mathrm{a}) \mathrm{cml}$ and M. xanthus $\mathrm{AI}(\mathrm{RI} \cdot 19) \mathrm{cml}$ is consistent with the origin of the strains as exconjugants from mixtures with $\mathrm{R}^{+}$strains of $E$. coli (Parish, 1975). From the present data, we cannot say whether or not the plasmid (or some part thereof) has been transferred to Myxococcus. Our inability to demonstrate the presence of plasmids associated with chloramphenicol resistance in other $M$. fullus strains may reflect either low yields of the $\mathrm{R}$ factor relative to the cryptic plasmids of $M$. fulius $\mathrm{M}$ or integration of the plasmid into the genome.

This work was supported by the Science Research Council with a studentship to (N.L.B.) and a research grant (to J.H.P). 


\section{REFERENCES}

Abelson, J. \& Thomas, C. A., JR. (1966). The anatomy of the T5 bacteriophage DNA molecule. Jouraal of Molecular Biology 18, 262-29I.

Burchard, R. P. \& Dworkin, M. (I966). Light-induced lysis and carotenogenesis in Myxococcus xanthus. Journal of Bacteriology 91, 535-545.

Burchard, R. P. \& Parish, J. H. (1975). Chloramphenicol resistance in Myxococcus xanthus. Antimicrobial Agents and Chemotherapy 7, 233-238.

Burgi, E. \& Hershey, A. D. (1963). Sedimentation rate as a measure of molecular weight of DNA. Biophysical Journal 3, 309-321.

Carlton, B. C. \& SMith, M. P. W. (1974). Size distribution of the closed circular deoxyribonucleic acid molecules of Bacillus megaterium: sedimentation velocity and electron microscope measurements. Journal of Bacteriology II7, I201-1209.

Flamm, W. G., Birnstiel, M. L. \& Walker, P. M. B. (1972). Isopycnic centrifugation of DNA: methods and applications. In Subcellular Components, 2nd edn, pp. 279-310. Edited by G. D. Birnie. London and Baltimore: Butterworths and University Park Press.

Guerry, P., LeBlanc, D. J. \& Falkow, S. (1973). General method for the isolation of plasmid deoxyribonucleic acid. Journal of Bacteriology 116, 1064-1066.

Hennebury, R. C. \& Carlton, B. C. (I973). Characterization of the polydisperse closed circular deoxyribonucleic acid molecules of Bacillus megaterium. Journal of Bacteriology 114, 625-63I.

PARISH, J. H. (I975). Transfer of drug resistance to Myxococcus from bacteria carrying drug resistance factors. Journal of General Microbiology 87, 198-2 I0.

Vinograd, J., Lebowitz, J. \& Watson, R. (I968). Early and late helix-coil transitions in closed circular DNA. The number of superhelical turns in polyoma DNA. Journal of Molecular Biology 33, 173-197. 